\title{
Relation between Obstetric Outcome and Parity
}

\author{
Helene Warde Chami*, Mamour Gueye, Mame Diarra Ndiaye, Mouhamadou Wade, Aliou Diouf, \\ Abdoulaye Diakhate, Simon Birame Ndour, Ndama Niang, Magatte Mbaye
}

Gynaecologic and Obstetric Clinic, Aristide Le Dantec Teaching Hospital, Cheikh Anta Diop University, Dakar, Senegal

Email: ^helene.chami@gmail.com

How to cite this paper: Chami, H.W., Gueye, M., Ndiaye, M.D., Wade, M., Diouf, A., Diakhate, A., Ndour, Si.B., Niang, N. and Mbaye, M. (2019) Relation between Obstetric Outcome and Parity. Open Journal of Obstetrics and Gynecology, 9, 894-903.

https://doi.org/10.4236/ojog.2019.96087

Received: May 20, 2019

Accepted: June 25, 2019

Published: June 28, 2019

Copyright $\odot 2019$ by author(s) and Scientific Research Publishing Inc. This work is licensed under the Creative Commons Attribution International License (CC BY 4.0).

http://creativecommons.org/licenses/by/4.0/

\begin{abstract}
Objectives: To evaluate the prognosis of obstetric complications by parity in a suburban center in Dakar. Patients and Method: We conducted a retrospective and prospective, cross-sectional study that evaluated all women admitted to the Philippe Maguilen Senghor Health Center for the management of their pregnancy (childbirth, abortion, ectopic pregnancy), whether they were primiparous or multiparous. The data for this study covered a 66-month period, from January 1, 2012 to June 30, 2017. Data were entered into our E-perinatal computer database. They were then extracted and analyzed first on Microsoft Excel 2016 and then on SPSS 24, Windows version. Results: Between January 2012 and June 2017, we've registered 27,441 patients including 25,905 deliveries, 1415 abortions and 121 ectopic pregnancies. Direct obstetric complications involved $14.1 \%$ of our patients. $12.1 \%$ multiparous and $17.3 \%$ primiparous had at least one direct obstetric complication of World Health Organization (WHO). Antepartum haemorrhage, uterine rupture, ectopic pregnancy, and abortion complications were more common in multipara, whereas prolonged and obstructed labor, preeclampsia, and eclampsia were more common in primiparous women. Postpartum haemorrhage occurred at substantially equal frequencies in both parity groups. We had not found any case of sepsis. Conclusion: Our study confirms that primiparity is a factor that may lead to obstetric complications. However, while some complications were more common in the primiparous, others were exclusive to multiparous when we did not expect it. We also recommend continuing this work by singling out multiparas and large multiparas, in order to better understand the obstetric prognosis linked to parity.
\end{abstract}

\section{Keywords}

Direct Obstetric Complications, Primiparous, Multiparous

\section{Introduction}

At the dawn of the third millennium, the drama of maternal mortality remains 
the same, a scourge that strikes hard on our developing countries and particularly Africa, where the very precarious socio-economic, environmental and health conditions expose women to the complications of pregnancy and childbirth [1]. Approximately 830 women die every day in the world because of complications related to pregnancy or childbirth. About $99 \%(302,000)$ of the world's maternal deaths in 2015 occurred in developing countries, with sub-Saharan Africa alone accounting for $66 \%$ of deaths $(201,000)$, followed by South Asia $(66,000)$. In Senegal, maternal mortality was estimated in 2015 at 315 maternal deaths per 100,000 live births [1].

About $15 \%$ of women develop a complication during pregnancy that requires the intervention of qualified healthcare provider [1]. In about $5 \%$ of cases, these complications can be life-threatening [2]. Approximately $80 \%$ of maternal deaths result directly from complications of pregnancy, childbirth, or the puerperium.

Intra-partum risk is based primarily on the past obstetrical history that is lacking in all primiparity. There are fundamental differences between the normal delivery of a primiparity and that of a multipara. Compared to multipara, primiparity is more likely to develop labor abnormalities that require intervention [3]. Numerous studies have shown that first pregnancies are at an increased risk of complications during pregnancy, labor and delivery, and if not properly managed, these complications can lead to increased morbidity and mortality of both the woman and her child [4].

The direct obstetric complications considered in this article are prolonged and obstructed labor, severe pre-eclampsia and eclampsia, ante or postpartum haemorrhage, uterine rupture, postpartum sepsis, complications of abortion and ectopic pregnancy [5].

This paper aims to determine the association between parity and obstetric complications.

\section{Patients and Method}

We conducted a retrospective and prospective, cross-sectional study, which evaluated all women admitted to the Philippe Maguilen Senghor Health Center (CSPMS) for the management of their pregnancy (childbirth, abortion, ectopic pregnancy), whether they were primiparous or multipares.

The data for this study covered a 66-month period from January 1, 2012 to June 30, 2017.

Were included in the study, all patients admitted from January 1, 2012 to June 30,2017 , for the management of their pregnancy, regardless of the parity or admission method.

We did not include in the study incomplete files (where one variable was missed).

Data were entered into our e-Perinatal computer database. They were then extracted and analyzed first on Microsoft Excel 2016 and then on Statistical Package for Social Science (SPSS 24), Mac version. 
For each patient, we collected and analyzed the socio-demographic characteristics; data on pregnancy and childbirth; pathologies associated with pregnancy (hypertension, diabetes, premature rupture of membranes); direct obstetric complications (antepartum haemorrhage and postpartum haemorrhage, prolonged labor and dystocia, severe pre-eclampsia, uterine rupture, puerperal infection); maternal mortality; parameters related to the newborn (birth weight, Apgar score, fetal status at birth).

Continuous quantitative variables were described by their position and dispersion parameters: mean, median, mode, standard deviation. They were compared using the ANOVA (ANalysis Of VAriance) test.

The qualitative variables were described by proportions in relation to the total share. They were compared using the chi-square test were applicable or by non-parametric tests in the opposite case.

Comparisons of multiple proportions were also made using the chi-square test or non-parametric tests. If inter-group comparisons were significant, the adjusted standardized residuals were calculated (adjusted z-scores) and their adjusted alpha risk significance threshold adjusted for the number of adjusted values.

The level of significance used was 0.05 .

\section{Results}

Between January 1, 2012 and June 30, 2017, we recorded 27,441 patients, including 25,905 deliveries.

The average age of the patients was 27 years with extremes of 11 and 53 years. More than half of the sample (54.5\%) were aged between 20 and 29 years old.

We registered 18,655 (72\%) vaginal deliveries and $7250(28 \%)$ cesarean sections.

Out of the 27,441 patients, 3864 (14.1\%) had a direct obstetric complication.

During the period study, 29 deaths occurred leading to a maternal mortality ratio (MMR) of 115.8 per 100,000 live births; $58.6 \%$ were multiparous and $41.4 \%$ were primiparous.

The majority (41.4\%) of the patients had died within 24 hours of delivery.

$86.2 \%$ of maternal deaths cases were caused by a direct obstetric cause dominated by haemorrhage and eclampsia, $3.5 \%$ of cases were due to indirect obstetric causes while non-obstetric ones amounted to $10.3 \%$.

Preterm and post-term deliveries rates were slightly higher in the primiparous group.

Abnormal presentations (breech, transverse), were more frequent in multipara (6.1\%) than in primipara (5.1\%).

Caesarean section was slightly more common in primiparous $(28.4 \%)$ than in multiparous women $(27.7 \%)$. This difference is not statistically significant $(\mathrm{p}=$ $0.219)$.

The primipara was more likely to be operated on for mechanical obstructed labor, eclampsia, acute fetal distress or convenience. Multiparous tended to be operated for dynamic dystocia, funicular dystocia, obstructed labor, labor failure 
or multiple pregnancy.

Stillbirths were more common in multiparas (3.4\%) than in primiparous $(3.2 \%)$. The difference was not statistically significant $(\mathrm{p}=0.287)$. Primiparous women were more likely to have newborns with an Apgar score less than 7 in the first minute of life (17.6\%), and newborns with a birth weight of less than 2500 grams were more common in primiparous women $(14.4 \%)$.

Regarding other pathologies of pregnancy, the occurrence of gestational diabetes was identical for multiparas and primiparous, representing for each, $2 \%$ of patients.

Premature rupture of membranes and hypertension were more common in primiparous than in multiparous patients with $7.8 \%$ and $5.1 \%$, respectively.

$12.1 \%$ multiparous and $17.3 \%$ primiparous had at least one direct obstetric complication according to the World Health Organization (WHO) classification (Table 1). This difference is statistically significant.

Overall, antepartum haemorrhage, uterine rupture, ectopic pregnancy, and abortion complications were more common in multiparous, whereas prolonged and obstructed labor, preeclampsia and eclampsia were more common in primiparous (Table 2). Postpartum haemorrhage occurred at substantially equal frequencies in both groups as shown.

Table 1. Distribution of patients according to obstetric complications and parity.

\begin{tabular}{|c|c|c|c|c|}
\hline \multirow[t]{2}{*}{ Direct obstetric complications } & \multicolumn{2}{|c|}{ Parity } & \multirow[t]{2}{*}{ Total } & \multirow[t]{2}{*}{$\mathrm{p}$} \\
\hline & $\begin{array}{l}\text { Multipara } \\
\text { N (\%) }\end{array}$ & $\begin{array}{c}\text { Primipara } \\
\mathrm{N}(\%)\end{array}$ & & \\
\hline \multirow[t]{2}{*}{ Yes } & $2069(12.1)$ & $1795(17.3)$ & $3864(14.1)$ & \\
\hline & & & & $<0.001$ \\
\hline No & $14,981(87.9)$ & $8596(82.7)$ & $23,577(85.9)$ & \\
\hline
\end{tabular}

Table 2. Distribution of patients according to type of obstetric complications and parity.

\begin{tabular}{|c|c|c|c|c|}
\hline \multirow[t]{2}{*}{ Obstetric complications } & \multicolumn{2}{|c|}{ Parity } & \multirow[t]{2}{*}{$\begin{array}{l}\text { Total } \\
\text { N (\%) }\end{array}$} & \multirow[t]{2}{*}{$\mathrm{p}$} \\
\hline & $\begin{array}{c}\text { Multipara } \\
\text { N (\%) }\end{array}$ & $\begin{array}{c}\text { Primipara } \\
\mathrm{N}(\%)\end{array}$ & & \\
\hline \multicolumn{5}{|c|}{ Pregnancy and childbirth complication's $(n=25,905)$} \\
\hline Prolonged and obstructed labor & $1160(7.2)$ & $1240(12.5)$ & $2400(9.3)$ & $<0.001$ \\
\hline Preeclampsia and eclampsia & $404(2.5)$ & $355(3.6)$ & $759(2.9)$ & $<0.001$ \\
\hline Antepartum hemorrhage & $384(2.4)$ & $158(1.6)$ & $542(2.1)$ & $<0.001$ \\
\hline Postpartum hemorrhage & $44(0.3)$ & $23(0.2)$ & $67(0.3)$ & 0.510 \\
\hline Uterine rupture & $40(0.2)$ & $3(0.0)$ & $43(0.2)$ & $<0.001$ \\
\hline \multicolumn{5}{|c|}{ Ectopic Pregnancy $(n=121)$} \\
\hline Ectopicpregnancy & $69(57)$ & $52(43)$ & 121 & - \\
\hline \multicolumn{5}{|c|}{ Abortion complications $(n=79)$} \\
\hline Abortion complications & $45(57)$ & $34(43)$ & 79 & - \\
\hline
\end{tabular}




\section{Discussion}

The retrospective nature of the study involves a significant recording bias, as the data are collected from the records of patients already discharged from the Philippe Maguilen Senghor Health Center (CSPMS). Some parameters could have been omitted. However, this weakness has been corrected since 2016. In addition, we did not have any information concerning the state of health of the patients at the time of the post-natal visits; this factor may have contributed to underestimating maternal and neonatal morbidity and mortality rates.

Direct obstetric complications involved $14.1 \%$ of our patients. Our rate is relatively acceptable since participants in the World Health Organization (WHO) technical consultation decided to keep the estimate of the frequency of serious complications at $15 \%$ for the purposes of the assessment of Obstetric Care needs and Neonatal Urgency (SONU) [5]. Dia [6] found a rate of $8.1 \%$ of expected complications actually recorded and managed.

The various studies devoted to this question have given a whole range of results. For example, a prospective population study in six West African countries found that $6 \%$ of pregnant women had serious direct obstetric complications [7]. The authors indicate that their observations probably underestimate the reality because the terminology used to define complications was linked to medical interventions that may not be practicable in the health facilities under investigation. A prospective study of deliveries in India found an incidence of $17.7 \%$ for direct obstetric complications during labor [8]. However, these studies did not consider complications during pregnancy (complications of abortion and ectopic pregnancies), so the actual percentage of women with direct complications was probably higher.

$12.1 \%$ of multiparous and $17.3 \%$ of primiparous women had at least one direct obstetric complication. Fall [9] and Kane [10] found in their studies a higher rate of obstetric complications in primiparous.

Regarding parity, the data in our study are consistent with those in the literature where antepartum haemorrhage is much more common in multiparas. Like Dièye [11], antepartum haemorrhage was present in $2.4 \%$ of multiparas whereas this was the case for only $1.6 \%$ of primiparous women. The risk in these parturients is due to the weakening of the uterus due to the numerous and fast rate of pregnancies.

Postpartum haemorrhage (PPH) occurred at relatively equal frequencies in multiparous $(0.3 \%)$ and primiparous $(0.2 \%)$, unlike literature data where $\mathrm{PPH}$ occurred more frequently in multipara and grand multipara. Keita [12] found a rate of $36.3 \%$ in multipara and grand multipara, Alihonou [13], a rate of $60.3 \%$.

We have noted the prevalence of dystocia and prolonged labor among primiparous women with a rate of $12.5 \%$ against $7.2 \%$ in multiparas. Several studies have shown that, compared with multiparous women, nulliparas have a longer labor of delivery [14] [15], are at increased risk of intrapartal complications and undergo practically more obstetric interventions [16] [17] [18]. 
The results of our study are consistent with literature data that considers primiparity to be one of the most important risk factors [19]. Preeclampsia was more common in primiparous women than in multiparous women, with a rate of $3.6 \%$ versus $2.5 \%$. According to Edouard [19], it is the notion of parity that explains the high risk of preeclampsia and eclampsia in young women and not maternal age. For Goffinet, pre-eclampsia is 3 to 4 times more common in primiparous than in multiparous. As in other studies [20] [21], our study showed a very significant association between primiparity and hypertension disorders.

Uterine rupture is a real barometer in the management of obstetric emergencies. It is considerably influenced by the socio-economic level of the countries [22] [23].

During our study period, 25,905 deliveries were registered in the department, including 43 uterine rupture. The frequency of uterine rupture is $0.2 \%$, i.e. 1 uterine rupture for 602 deliveries. Compared to literature data, our frequency is lower than those reported by other studies in Africa. Guèye et al. [24] found a frequency of $0.58 \%$ ( 1 uterine rupture for 172 deliveries). Diakité [25] found a frequency of $0.37 \%$ ( 1 uterine rupture for 268 deliveries). Other studies in sub-Saharan Africa found relatively high frequencies: $0.36 \%$ in Dakar [23], $0.6 \%$ in the Central African Republic [26], 0.78\% in Togo [27], 1.15\% in Bamako [22] and 2.33\% in Niger [28].

On the other hand, our figure remains high compared to the developed countries, where the uterine rupture constitutes an exceptional situation with a rate of 1/1000 to 1/2000 live births in France [29] and a rate lower than 1/1000 deliveries in the United States [30].

This high frequency could be explained by late evacuations and poor antenatal care, inadequate supervision of childbirth. These lower rates are underpinned by better access to health care and higher-quality technical platforms that are better suited for the treatment of uterine rupture [31].

In contrast to highly medicalized countries where uterine rupture, usually a result of disunion of uterine scars, occurring once in every 10,000 deliveries [25], this pathology still appears to be commonplace in developing countries, where it is a major problem.

The high frequency of uterine rupture in these different countries is the consequence of the lack of control of risk factors during pregnancy and delivery [32].

As for Bohoussou [32], Bayo [33] and Diouf [34], the frequency of uterine rupture increases with parity. Multiparity through histological changes of the uterine muscle can cause uterine rupture. To this is added a uterus weakened by a uterine scar. We are of the same opinion as Bohoussou [32], Bayo [33], Traoré [35] who found that the predisposition of multiparas to uterine rupture is a classic notion that deserves to be preserved by increased vigilance [25] [36]. Also, we have noticed the prevalence of uterine rupture among multiparas as in Burkina Faso [37], Ivory Coast [38], Iraq [39], and Benin [40].

During the study period, 1415 patients had an abortion out of a total of 27,441 inmates. Of these patients, 79 had an abortion complication. The frequency of 
complicated abortion is $0.3 \%$ of the total number of patients, i.e. 1 complicated abortion for 347 patients. Complications of abortion were more common in multiparous women (57\%).

In addition, 121 patients had ectopic pregnancy out of a total of 27,441 patients. The frequency of ectopic pregnancy was $0.4 \%$ compared to the total number of patients, i.e. 1 ectopic pregnancy for 227 patients. The incidence of ectopic pregnancy in our series is consistent with that of the literature which varies between $0.51 \%$ and $2 \%$. For the study conducted in Senegal by Cissé [41], the incidence of ectopic pregnancy was estimated at 0.6 per 1000 expected pregnancies. Ndong [42] found a frequency of $0.8 \%$. The ectopic pregnancy occurred more frequently in the multiparous (57\%). Some authors [43] [44] [45] believe that nulliparity is a risk factor for ectopic pregnancy. But for Cissé [41], in 56\% of cases there were patients having had at least 3 previous deliveries with an average parity of 3. For other authors such as Coste and al. [46], in France, there was no link between parity and the occurrence of an ectopic pregnancy.

\section{Conclusion}

The relationship between parity and the complications of pregnancy continues to be of interest to obstetricians. Some authors consider primiparity as a marker of risk; others have concluded that parity does not influence the outcome of pregnancy. Our study confirms that primiparity is a source of obstetric complications. However, some complications were more common in primiparity and others were more likely to occur in multiparas. We also recommend continuing this work by singling out multiparas and large multiparas, in order to better understand the obstetric prognosis linked to parity.

\section{Ethical Considerations}

The Dakar Teaching Hospital Ethical committee approved this study.

\section{Conflicts of Interest}

The authors declare no conflicts of interest.

\section{References}

[1] Organisation mondiale de la Santé (2004) Prise en charge des complications de la grossesse et de l'accouchement: Guide destiné à la sage-femme et au médecin. Genève: OMS.

[2] Organisation Mondiale de la Santé (2000) Pour une grossesse à moindre risque-Rapport du secrétariat. Cent Septième Session.

[3] Adeyemi, A.S., Adekanle, D.A. and Afolabi, A.F. (2014) Predictors of Vaginal Delivery in Nulliparous Mothers. Annals of African Medicine, 13, 35-40. https://doi.org/10.4103/1596-3519.126949

[4] Ojiyi, E., Anozie, U., Dike, E., Okeudo, C., Anolue, F., Uzoma, O., et al. (2012) Pregnancy Outcome in Primigravidae in A Tertiary Hospital: A Three-Year Review. The Internet Journal of Gynecology and Obstetrics, 16, 1-5. 
[5] World Health Organization (2009) Monitoring Emergency Obstetric Care Handbook. Geneva.

[6] Dia, M. (2016) Soins obstétricaux et néonatals d'urgence au district sanitaire ouest de Dakar: Évaluation de l'offre de 2011 à 2013. Thèse: Méd. Université Cheikh Anta Diop, Dakar.

[7] Prual, A., Bouvier-Colle, M.-H., De Bernis, L., Breart, G., et al. (2000) Morbidité maternelle grave par causes obstétricales directes en Afrique de l'Ouest: Incidence et létalité. Bulletin de P Organisation Mondiale de la Santé, 78, 593-602.

[8] Bang, R.A. (2004) Maternal Morbidity during Labour and the Puerperium in Rural Homes and the Need for Medical Attention: A Prospective Observational Study in Gadchiroli, India. BJOG: An International Journal of Obstetrics and Gynaecology, 111, 231-238. https://doi.org/10.1111/j.1471-0528.2004.00063.x

[9] Fall, C. (2015) Soins obstétricaux et néonatals d'urgence: Aspects épidémiologiques, cliniques et thérapeutiques au Centre de Santé de Kédougou. Thèse: Méd. Université Cheikh Anta Diop, Dakar.

[10] Kane, K. (2013) Pratique de l'excision et morbi-mortalité maternelle et périnatale dans le département de Ranérou-Ferlou à Matam (Sénégal). Thèse: Méd. Université Cheikh Anta Diop, Dakar.

[11] Dièye, M. (2015) Evaluation de la prise en charge des metrorragies du troisième trimestre de la grossesse au Centre Hospitalier Régional de Ndioum en 2013 (Saint Louis/ Sénégal). Thèse: Méd. Université Cheikh Anta Diop, Dakar.

[12] Keita, S. (2003) Etude des hémorragies du post-partum dans le service de gynécologie-obstétrique de l'Hôpital du Point G-Bamako 1991-2001. Thèse: Méd. Université de Bamako, Bamako.

[13] Alihonou, E. (2002) Les hémorragies de la délivrance: Etude statistique et Etiologique (à propos de 151 cas recensés en 5 ans). Publication Médicale Africaine, 121, 8-11.

[14] Vahratian, A., Hoffman, M.K., Troendle, J.F. and Zhang, J. (2006) The Impact of Parity on Course of Labor in a Contemporary Population. Birth, 33, 12-17. https://doi.org/10.1111/j.0730-7659.2006.00069.x

[15] Schiessl, B., Janni, W., Jundt, K., Rammel, G., Peschers, U. and Kainer, F. (2005) Obstetrical Parameters Influencing the Duration of the Second Stage of Labor. European Journal of Obstetrics \& Gynecology and Reproductive Biology, 118, 17-20. https://doi.org/10.1016/j.ejogrb.2004.01.045

[16] Malkiel, A., Mor, P., Aloni, H., Gdansky, E. and Grisaru-Granovsky, S. (2008) Primiparity: a Traditional Intrapartum Obstetric Risk Reconfirmed. The Israel Medical Association Journal, 10, 508-511.

[17] Selin, L., Wallin, G. and Berg, M. (2008) Dystocia in Labour-Risk Factors, Management and Outcome: A Retrospective Observational Study in a Swedish Setting. Acta Obstetricia et Gynecologica Scandinavica, 87, 216-221. https://doi.org/10.1080/00016340701837744

[18] Hashim, N., Naqvi, S., Khanam, M. and Jafry, H.F. (2012) Primiparity as an Intrapartum Obstetric Risk Factor. Journal of Pakistan Medical Association, 62, 694-698.

[19] Edouard, D. (2003) Toxémie gravidique. In: Karman, S., Ed., Anesthésie réanimation chirugicale, 3ème edition, Flammarion, Paris, 1211-1221.

[20] Ziadeh, S. and Yahaya, A. (2001) Pregnancy Outcome at Age 40 and Older. Archives of Gynecology and Obstetrics, 265, 30-33.

https://doi.org/10.1007/s004040000122 
[21] Chaibva, C.N., Ehlers, V.J. and Roos, J.H. (2010) Midwive's Perceptions about Adolescent's Utilisation of Public Prenatal Services in Bulawayo, Zimbabwe. Midwivery, 26, e16-e20. https://doi.org/10.1016/j.midw.2009.01.001

[22] Dolo, A., Keita, B., Diabaté, F.S. and Maiga, B. (1991) Les ruptures utérines au cours du travail. A propos de 21 cas observés au Service de Gynécologie-Obstétrique de l'Hôpital Point G, Bamako. Médecine d Afrique Noire, 38, 133-134.

[23] Cissé, M.L., Sylla, M.A., Gaye, A., Bâ-Guèye, M., Guèye, M., Diouf, A., et al. (2009) La rupture utérine en banlieue dakaroise (Sénégal). Annales de la SOGGO, 4, 11-15.

[24] Guèye, L., Thiam, M., Niang, M.M., Sarr, F.R., Ba, P.A., Mahamat, S., et al. (2016) Ruptures utérines à l'hopital régional de Thiès (Sénègal). Journal de la $S A G O, 17$, 28-32.

[25] Diakite, Y. (2011) La rupture utérine au centre de santé de référence de la commune $\mathrm{V}$ du district de Bamako. Thèse: Méd. Université de Bamako, Bamako.

[26] Sépou, A., Yanza, M.C., Nguembi, E., et al. (2002) Les ruptures utérines à la Maternité de l'Hôpital Communautaire de Bangui (Centrafrique). Medecine Tropical, 62, 517-520.

[27] Akpadza, K., Baeta, S. and Hodonou, A.K.S. (1996) Fréquence et pronostic des quatre grandes urgences médico-obstétricales du Centre Hospitalier Régional de Sokode (Togo). Médecine d Afrique Noire, 43, 592-595.

[28] Diallo, F.B., Idi, N., Vangeenderhuysen, C. and Barake, D. (1998) La rupture utérine à la maternité centrale de référence de Niamey (Niger). Aspects épidémiologiques et stratégies de prévention. Médecine d Afrique Noire, 45, 310-315.

[29] Bretones, S., Cousin, C., Gualandi, M. and Melli, G. (1997) Uterine Rupture. A Case of Spontaneo Rupture in a Thirty Week Primiparous Gestation. Journal of Gynecology Obstetrics and Human Reproduction, 26, 324-327.

[30] Ozdemir, I., Yucel, N. and Yucel, O. (2005) Rupture of the Pregnant Uterus: A 9-Year Review. Archives of Gynecology and Obstetrics, 272, 229-231. https://doi.org/10.1007/s00404-005-0733-3

[31] Gassama, O., Niang, M.M., Diouf, A.A., Touré, Y., Mbodj, A., Faye Dieme, M.E., et al. (2017) Uterine Ruptures during Labor: A Study of 26 Cases at Nabil Choucair Medical Center, in the Suburbs of Dakar. International Journal of Reproduction, Contraception, Obstetrics and Gynecology, 6, 2154-2157. https://doi.org/10.18203/2320-1770.ijrcog20172306

[32] Bohoussou, K., Houphouet, K.B., Anoma, M. and Sangaret, M.A. (1978) Ruptures utérines au cours du travail. A propos de 128 cas. Medecine d'Afrique Noire, 17, 467-478.

[33] Bayo, A. (1991) Les ruptures utérines à propos de 58 cas recensés à l'hopital Gabriel Touré. Thèse: Méd. Université de Bamako, Bamako.

[34] Diouf, A., Dao, B., Diallo, D., Moreira, P. and Diadhiou, F. (1995) Les ruptures utérines au cours du travail d'accouchement: expérience d'une maternité de référence à Dakar (Sénégal). Médecine d’ Afrique Noire, 42, 594-597.

[35] Traore, Y. (1996) Les ruptures utérines à l'hopital national du point G: Facteurs influençant le pronostic materno fotal et mesures prophylactiques a ' propos de 180 cas. Thèse: Méd. Université de Bamako, Bamako.

[36] Sidibé, A.K. (1990) L'anesthésiste réanimateur face aux hémorragies obstétricales graves à l'Hôpital Gabriel Touré. Thèse: Méd. Université de Bamako, Bamako.

[37] Akotionga, M., Lankoande, J., Gue, M.J. and Kone, B. (1998) Ruptures Utérines à la 
maternité du CHN-YO. Aspects épidémiologiques et cliniques. Médecine d Afrique Noire, 45, 308-310.

[38] Kouakou, P., Djanhan, Y., Doumbla, Y., Djanhan, L. and Ouattara, T. (2007) Les ruptures utérines: Aspects épidémiologiques et pronostic foto-maternel à la maternité du CHU de Bouaké (Côte d'Ivoire). Revue Cames-Série A, 5, 87-91.

[39] Yalda, M.A. and Munib, A. (2009) Rupture utérine à Dohuk (Iraq). Revue de Santé de la Méditerranée Orientale, 15, 1273-1277.

[40] Kabibou, S., Sambo, B.T., Tchaou, B.A., Sidi, R., Denakpo, J., Lokossou, A., et al. (2015) Les ruptures utérines à l'hopital de référence de Parakou au Bénin: Aspects épidémiologiques, thérapeutiques et pronostiques. European Scientific Journal, 11, 149-160.

[41] Cissé, C.T., De Bernis, L., Eho, F. and Diadhiou, F. (2002) Grossesse extra-utérine au Sénégal. Cahiers d Études et de Recherches Francophones, 12, 271-274.

[42] Ndong, S.I. (2014) Grossesse extra-utérine: Aspects épidémiologiques, diagnostiques et thérapeutiques au centre hospitalier régional de Ndioum à propos de 30 cas Thèse: Méd. Université Cheikh Anta Diop, Dakar.

[43] Yao, I., Doukouré, B., Guie, P., N'Guessan, E., Bohoussou, K.P.E., Dia, J.M.L., et al. (2009) Grossesses extra utérines tubaires: Aspects épidémiologiques et histopathologiques de 40 cas colligés à la maternité du CHU de Treichville (Abidjan-Côte d'Ivoire). Revue Bio-Africa, 7, 44-49.

[44] Diallo, F.B., Diallo, A.B., Diallo, T.S., Camara, A.Y., Baldem, A., Diallo, Y., et al. (1999) Grossesse extra-utérine, aspects épidémiologique et thérapeutique au service de gynécologie obstétrique du CHU Ignace Deen de Conkry. Médecine d Afrique Noire, 46, 442-445.

[45] Picaud, A., Nlome-Nze, A.R., Faye, A., Kouvahe, V., Kpodar, D., Ouzouaki, F., et al. (1992) Evolution de la fréquence de la croissance de la grossesse extra utérine à Libreville (Gabon) de 1977 à 1989. Médecine d Afrique Noire, 39, 798-805.

[46] Coste, J., Bouyer, J. and Job, S.N. (1996) Epidémiologique de la grossesse extra-utérine. Incidence et facteurs de risque. Contraception, Fertilité, Sexualité, 24, 135-139. 